\title{
Stimulation of rat granulosa cell progesterone production but not other differentiated functions by a splenocyte-derived factor
}

\author{
J. M. Ness and B. G. Kasson* \\ Department of Pharmacology, College of Medicine, University of Iowa, Iowa City, IA 52242, USA
}

\begin{abstract}
Concanavalin A-stimulated splenocytes secrete a factor that stimulates progesterone production in cultured rat granulosa cells. The actions of this progesterone-stimulating factor (PSF) were characterized further by purifying it by sequential chromatographies on heparin-agarose, copper chelating-Sepharose and Mono S columns. Several of its effects on granulosa cells were then compared with those of FSH. Like FSH, PSF induced accumulation of progesterone and 20 $\alpha$-dihydroprogesterone in granulosa cell culture media; however, the time course of progesterone accumulation in response to PSF was much slower than that in response to FSH. In contrast to FSH, PSF induced little accumulation of oestrogen. Induction of other differentiated responses was compared by pretreating cultured granulosa cells with either FSH or PSF, and then challenging with $\mathrm{LH}$, prolactin, epidermal growth factor or the $\beta$-adrenergic agonist, isoproterenol. Pretreatment with FSH induced subsequent responsiveness to all four agents, whereas pretreatment with PSF induced subsequent responsiveness only to isoproterenol. These results indicate that granulosa cell responses to PSF are much more limited than are those to FSH and that these responses are characterized by an increase in progestin production.
\end{abstract}

\section{Introduction}

Mounting evidence suggests that there are complex interactions between the immune and endocrine systems. A variety of immune cells, including neutrophils, macrophages and T lymphocytes, are present in the ovary (Brännström et al., 1993). Several immune cell-derived mediators, including interleukins I and 6 , and tumour necrosis factor $\alpha$, modulate granulosa cell steroidogenesis, typically in an inhibitory fashion (Kasson and Gorospe, 1989; Veldhuis et al., 1991; Gorospe et al., 1992). In contrast, we have shown that rat splenocytes secrete a factor that stimulates progesterone production in freshly isolated, undifferentiated granulosa cells obtained from female weanling rats pretreated with diethylstilboestrol (Gorospe and Kasson, 1988). This progesterone-stimulating factor (PSF) is distinct from $\mathrm{FSH}$, epidermal growth factor (EGF), GnRH, vasoactive intestinal peptide (VIP) and pituitary adenylate cyclaseactivating peptide (PACAP), the main agents shown to induce steroidogenesis independently in undifferentiated granulosa cells (Clark, 1982; Jones et al., 1982; Hsueh et al., 1984; Davoren and Hsueh, 1985; Zhong and Kasson, 1994). The actions of PSF are also unlike any previously tested cytokine in that they stimulate, rather than inhibit, steroidogenesis. The actions of PSF were characterized further by purifying it and comparing its effects on granulosa cells with those of FSH.

\section{Materials and Methods}

\section{Materials}

Ovine FSH (oFSH-16; FSH activity, $20 \times$ NIH FSH S1 units $\mathrm{mg}^{-1}$ ), ovine LH (oLH-25; LH activity, $2.3 \times \mathrm{NIH} \mathrm{LH} \mathrm{SI} \mathrm{units}$ $\left.\mathrm{mg}^{-1}\right)$, hCG (CR 125; $11900 \mathrm{iu} \mathrm{mg}^{-1}$ ) and ovine prolactin (oPRL-18; PRL activity $30 \mathrm{iu} \mathrm{mg}^{-1}$ ) were obtained from the National Hormone and Pituitary Program (NIDDK, NIH, Bethesda, MD). Concanavalin A, EGF (receptor grade) and isoproterenol were purchased from Sigma Chemical Co. (St Louis, MO). Ex-Cell 320 medium was obtained from JRH Biosciences (Lenexa, KS). McCoy's 5a medium (modified, without serum), L-glutamine and gentamicin were provided by The University of Iowa Diabetes and Endocrine Research Center.

\section{Splenocyte cultures}

Concanavalin A-stimulated culture supernatants were prepared as described by Gorospe and Kasson (1988) with some modifications. Briefly, adult male Sprague-Dawley rats (160$250 \mathrm{~g}$ ) were killed by asphyxiation with $\mathrm{CO}_{2}$, following procedures approved by the Institutional Animal Care and Use Committee of the University of Iowa. Their spleens were aseptically removed, washed in culture media and pressed through a sterile stainless steel screen $(80 \mu \mathrm{m}$ mesh) to obtain individual splenocytes. The cells were washed twice by centrifugation $(600 \mathrm{~g}, 5 \mathrm{~min})$, resuspended in serum-free media (Ex-Cell 320) supplemented with $2.5 \mu \mathrm{g}$ concanavalin $\mathrm{A} \mathrm{ml}^{-1}$, Downloaded from Bioscientifica.com at 04/26/2023 01:09:50PM 
$50 \mu \mathrm{mol} \beta$-mercaptoethanol $\mathrm{l}^{-1}$ and $50 \mu \mathrm{g}$ gentamicin $\mathrm{ml}^{-1}$ and incubated in T-75 flasks $\left(7.5 \times 10^{8}\right.$ cells per $\left.50 \mathrm{ml}\right)$ at $37^{\circ} \mathrm{C}$ in $95 \%$ air : $5 \% \mathrm{CO}_{2}$ for $48 \mathrm{~h}$. Conditioned medium was collected, centrifuged $\left(3000 \mathrm{~g}, 20 \mathrm{~min}, 4^{\circ} \mathrm{C}\right)$ to remove any non-adherent cells, and precipitated with ammonium sulfate. The $50-90 \%$ cut was dialysed against $50 \mathrm{mmol}$ Tris- $\mathrm{HCl} \mathrm{l}{ }^{-1}$, $\mathrm{pH} 7.4$ at $4^{\circ} \mathrm{C}$ and used as the starting material for purification of PSF.

\section{Granulosa cell cultures}

Female Sprague-Dawley rats, 21-22 days old (Harlan, Madison, WI) were implanted s.c. with $10 \mathrm{~mm}$ capsules (Baxter Healthcare, McGaw Park, IL) containing diethylstilboestrol, to induce granulosa cell proliferation. Rats were maintained under a photoperiod of $12 \mathrm{~h}$ light: $12 \mathrm{~h}$ dark with food and water ad libitum for 3-6 days and were then killed by asphyxiation with $\mathrm{CO}_{2}$ following procedures approved by the Institutional Animal Care and Use Committee of the University of lowa. Granulosa cells were expressed from isolated ovaries, using a 25-gauge needle. The cells were pelleted by centrifugation (100 $\mathrm{g}, 2 \mathrm{~min}$ ), washed once and resuspended in McCoy's $5 \mathrm{a}$ medium. Cells were plated at $5 \times 10^{4}$ viable cells per well in 24-well tissue culture cluster plates (Costar, Cambridge, MA) containing $0.5 \mathrm{ml}$ McCoy's 5 a medium supplemented with $50 \mu \mathrm{g}$ gentamicin $\mathrm{ml}^{-1}$ and $2 \mathrm{mmol} \mathrm{L-glutamine} \mathrm{ml}^{-1}$; androstenedione $\left(10^{-7} \mathrm{~mol} \mathrm{l}^{-1}\right)$ was also included, unless indicated otherwise. Cells were incubated at $37^{\circ} \mathrm{C}$ in a water-saturated atmosphere with 95\% air : $5 \% \mathrm{CO}_{2}$. At the indicated times, media were removed and stored at $-20^{\circ} \mathrm{C}$ for subsequent measurement of steroids.

\section{Steroid assays}

The progesterone and total oestrogen content of culture media were determined by enzyme-linked immunoassay using specific antisera as described in detail by Zhong and Kasson (1994). The intra-assay and interassay coefficients of variation for these assays were 7.3 and $10.2 \%$, respectively, for progesterone, and 8.2 and $10.9 \%$, respectively, for oestrogen. The sensitivity of both assays was $0.3 \mathrm{pg} \mathrm{ml}^{-1}$. The $20 \mathrm{\alpha}-$ dihydroprogesterone content of the culture media was determined by radioimmunoassay using a specific antiserum as described by Gorospe and Kasson (1988). The intra-assay and interassay coefficients of variation for this assay were 7.9 and $8.5 \%$, respectively. The sensitivity was $7.8 \mathrm{pg} \mathrm{ml}^{-1}$.

\section{FSH radioimmunoassay and radioreceptor assay}

For the FSH radioimmunoassay, reagents were obtained from the National Hormone and Pituitary Program (NIDDK, $\mathrm{NIH}$ ) and the assay was conducted following the protocol provided. For the radioreceptor assay, FSH (receptor grade, provided by L. Reichert, Albany Medical College, NY) was iodinated using the lactoperoxidase method as described by Miyachi et al. (1972). The assay was started by adding freshly isolated granulosa cells $\left(5 \times 10^{5}\right)$ to $12 \mathrm{~mm} \times 75 \mathrm{~mm}$ polypropylene tubes containing $0.2 \mathrm{ml}$ Dulbecco's phosphate-buffered saline (D-PBS) with $0.2 \%(\mathrm{w} / \mathrm{v}) \mathrm{BSA}$ and ${ }^{125}$ I-labelled FSH
( $1 \times 10^{5}$ c.p.m.) and increasing amounts of FSH or PSF. Cells were then incubated overnight at room temperature. The incubation was stopped by adding $2 \mathrm{ml}$ ice-cold PBS, and vacuum filtration was carried out through Whatman GF/C filters pre-soaked for $5 \mathrm{~min}$ in D-PBS-0.2\% (w/v) BSA. The filters were washed twice with $2 \mathrm{ml} \mathrm{D}$-PBS and the amount of radioactivity was measured. Nonspecific binding was determined by including excess FSH $(2 \mu \mathrm{g})$ in the incubation.

\section{Statistical analyses}

Radioimmunoassay and enzyme-linked immunoassay calculations and curve fitting were done using a 4-parameter logistic analysis program provided by $\mathrm{D}$. Rodbard (NIH). Different treatments were assessed by ANOVA and Newman-Keuls' multiple range test; $P<0.05$ was considered as a significant difference.

\section{Results}

\section{Purification of progesterone-stimulating factor}

Preliminary studies examining the binding of PSF to ion exchange columns indicated that most PSF activity bound well to cation exchange gels and that heparin-agarose provided the best purification. Consequently, purification was begun by loading dialysate (about $100 \mathrm{ml}$ ) from the ammonium sulfateprecipitated splenocyte culture supernatants onto a heparinagarose column $(15 \mathrm{~mm} \times 90 \mathrm{~mm})$. This column was then eluted at $0.5 \mathrm{mI} \mathrm{min}^{-1}$ with a $0-1 \mathrm{~mol} \mathrm{NaCl} \mathrm{l}^{-1}$ gradient in $50 \mathrm{mmol} \mathrm{NaPO}_{4} \mathrm{I}^{-1}, \mathrm{pH}$ 7.4. Two peaks of progesteronestimulating activity were obtained from this column; one peak was present in the flow-through and one peak was eluted by the $\mathrm{NaCl}$ gradient (Fig. Ia). Because the retained fraction contained most of the PSF, it was selected for further purification. Fractions containing active material (typically eluting between 0.3 and $0.4 \mathrm{~mol} \mathrm{NaCl} \mathrm{^{-1 }}$ ) were pooled, diluted threefold with 50 mmol $\mathrm{NaPO}_{4} \mathrm{l}^{-1}, \mathrm{pH} 7.4$, and rechromatographed on the heparin-agarose column. Active fractions were again pooled, diluted and applied to a copper-chelating Sepharose column ( $10 \mathrm{~mm} \times 60 \mathrm{~mm}$ ) which removed, among other substances, a major haem-protein contaminant (eluting at $20-30 \mathrm{mmol}$ imidazole $\mathrm{I}^{-1}$ ). This column was eluted at $0.5 \mathrm{ml} \mathrm{min}^{-1}$ with a $0-40 \mathrm{mmol}$ imidazole $\mathrm{l}^{-1}$ gradient in $150 \mathrm{mmol} \mathrm{NaCl} \mathrm{l}^{-1}, 10 \mathrm{mmol}$ Tris-HCl $\mathrm{l}^{-1}$, pH 7.4 (Fig. 1b). Active fractions from this column (typically eluting between 3.5 and 5 mmol imidazole $\mathrm{l}^{-1}$ ) were pooled, diluted threefold with 50 mmol $\mathrm{NaPO}_{4} \mathrm{l}^{-1}, \mathrm{pH} 7.4$, and applied to a Mono S FPLC cation exchange column $(7 \mathrm{~mm} \times 50 \mathrm{~mm})$ for high resolution ion exchange chromatography. This column was eluted at $0.7 \mathrm{ml} \mathrm{min}^{-1}$ with a $0-1$ mol $\mathrm{NaCl} \mathrm{l}^{-1}$ gradient in $50 \mathrm{mmol} \mathrm{NaPO} \mathrm{l}^{-1}, \mathrm{pH} 7.4$ (Fig. Ic). The active fractions from the Mono $\mathrm{S}$ column (typically eluting between 0.1 and $0.2 \mathrm{~mol} \mathrm{NaCl}{ }^{-1}$ ) were then pooled.

The efficiency of this purification procedure was monitored by following the PSF activity and protein content of the combined active fractions from each preparative step. The PSF activity was assessed by first constructing dose-response curves for granulosa cell progesterone production using Downloaded from Bioscientifica.com at 04/26/2023 01:09:50 

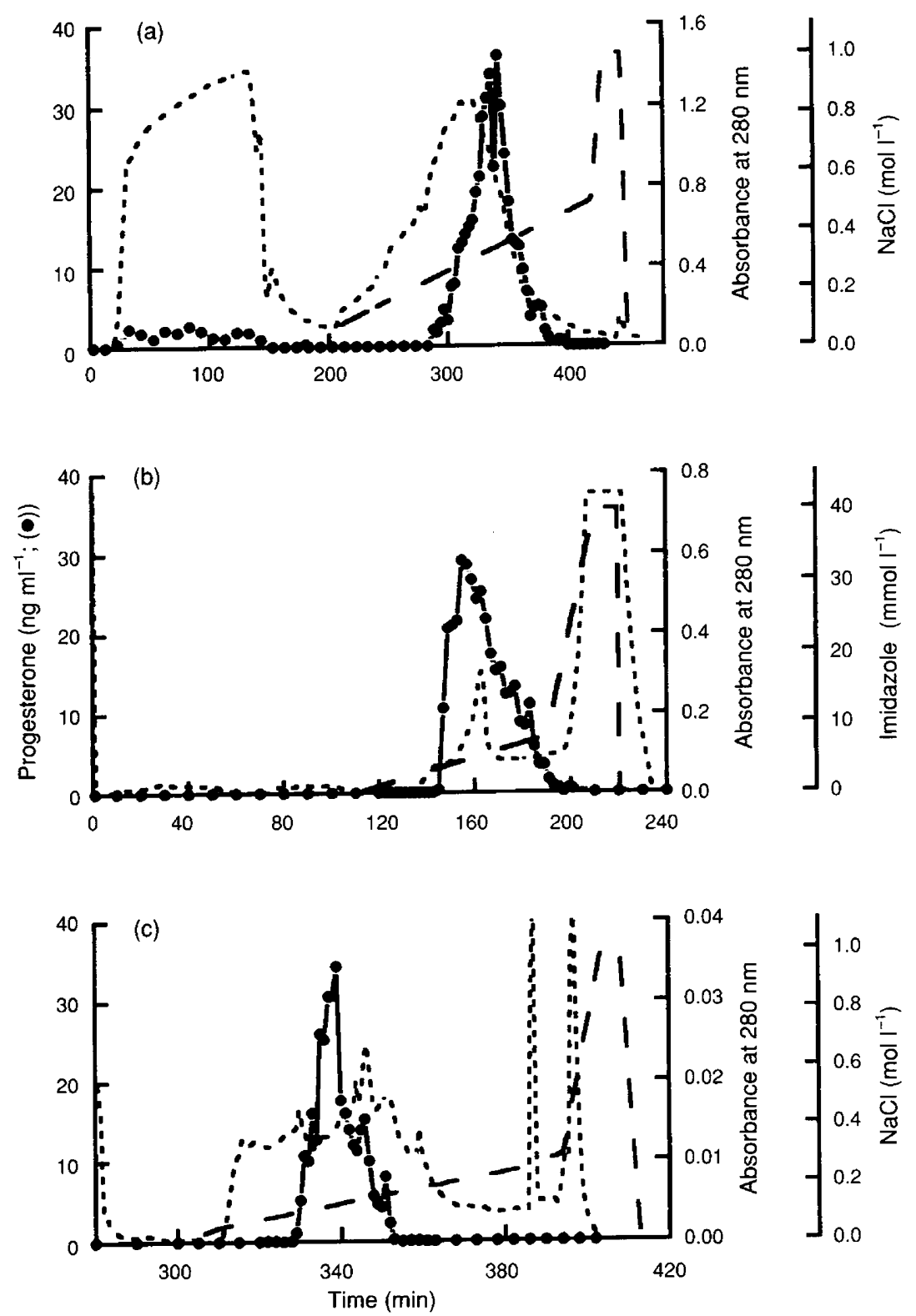

Fig. 1. Chromatographic profiles from the purification of progesterone-stimulating factor (PSF). (a) Dialysate from ammonium sulfate-precipitated conditioned media from concanavalin A-stimulated splenocytes, applied to a heparin-agarose column ( $15 \mathrm{~mm} \times 90 \mathrm{~mm}$ ) and eluted with a $0-1$ mol $\mathrm{NaCl} \mathrm{l}^{-1}$ gradient in 50 mmol $\mathrm{NaPO}_{4} \mathrm{I}^{-1}, \mathrm{pH}$ 7.4. (b) Combined and diluted active fractions from the heparin-agarose column, applied to a copper-chelating Sepharose column $(10 \mathrm{~mm} \times 60 \mathrm{~mm})$ and eluted with a $0-40 \mathrm{mmol}$ imidazole $1^{-1}$ gradient in $150 \mathrm{mmol} \mathrm{NaCl} \mathrm{l}{ }^{-1}, 10 \mathrm{mmol}$ Tris- $\mathrm{HCl} \mathrm{l}{ }^{-1}, \mathrm{pH} \mathrm{7.4.} \mathrm{(c)}$ Combined and diluted active fractions from the copper-chelating Sepharose column, applied to a Mono S FPLC cation exchange column $(7 \mathrm{~mm} \times 50 \mathrm{~mm})$ and eluted with a $0-1 \mathrm{~mol} \mathrm{NaCl} \mathrm{l}^{-1}$ gradient in $50 \mathrm{mmol} \mathrm{NaPO}_{4} \mathrm{l}^{-1}, \mathrm{pH}$ 7.4. Progesterone accumulation (-) in the media of granulosa cells cultured for 2 days with $20 \mu$ aliquots of each fraction; (-..) absorbance profile at $280 \mathrm{~nm}$; ( - - elution gradient.

increasing amounts of the combined active fractions from each PSF purification step. These dose-response curves showed similar maximal progesterone concentrations, except for those using conditioned media and dialysate, which produced maximal concentrations that were approximately $70 \%$ lower than material from subsequent steps. The PSF activity was then determined by defining one unit of activity as the amount required to produce half-maximal stimulation of progesterone $\left(\mathrm{ED}_{50}\right)$. The $\mathrm{ED}_{50}$ values were then determined from the dose-response curves by fitting the curves with the four 
Table 1. Purification of progesterone-stimulating factor (PSF)

\begin{tabular}{lccccc}
\hline Method & $\begin{array}{c}\text { Activity } \\
(\text { units })^{\mathrm{a}}\end{array}$ & $\begin{array}{c}\text { Protein } \\
(\mathrm{mg})\end{array}$ & $\begin{array}{c}\text { Specific activity } \\
\left(\mathrm{U} \mathrm{mg}^{-1}\right)\end{array}$ & $\begin{array}{c}\text { Purification } \\
(\text { fold })\end{array}$ & $\begin{array}{c}\text { Yield } \\
(\%)\end{array}$ \\
\hline Conditioned media $^{\mathrm{b}}$ & 37500 & 1255.0 & 30 & - & -1.5 \\
Dialysate $^{\mathrm{c}}$ & 36000 & 780.0 & 46 & 3.8 & 96 \\
Heparin-Sepharose I $_{\text {Heparin-Sepharose 2 }}$ & 30000 & 263.0 & 114 & 57.0 & 62 \\
Chelating-Sepharose & 23300 & 136.0 & 171 & 95.5 & 38 \\
Mono S & 14300 & 5.0 & 15546 & 518.2 & 23 \\
\hline
\end{tabular}

${ }^{a}$ One unit is defined as the amount of PSF required to produce half-maximal stimulation of progesterone production in cultured rat granulosa cells.

${ }^{b}$ Conditioned media was the media obtained after a treatment of cultured splenocytes for 2 days with $2.5 \mu \mathrm{g}$ concanavalin $\mathrm{A} \mathrm{ml}{ }^{-1}$. 'Dialysate was the material obtained after dialysing the 50-90\% ammonium sulfate fraction of conditioned splenocyte media against $50 \mathrm{mmol}^{\text {Tris }}-\mathrm{HCl} \mathrm{I}^{-1}$.

parameter logistic equation. Total activity was calculated by determining the number of units obtained at each preparative step. Specific activity was then determined by correcting for total protein, measured by the method of Bradford (1976). All values for each preparative step are given in Table 1. Using this method, the specific activity of the material from the Mono $S$ column was increased over 500 times from the starting material, with yields of $23 \%$ for total activity and $0.044 \%$ for total protein.

A silver stained SDS-PAGE, performed by the method of Laemmli (1970), of the combined active fractions from each preparative step (Fig. 2) revealed the presence of three major bands $\left(M_{\mathrm{r}}=66,60\right.$ and 37) and three minor bands $\left(M_{\mathrm{r}}=>200,76\right.$ and 18$)$ in the final Mono $S$ preparation (lane 5), a very limited number when compared with the starting material (lane 1). Further purification was attempted using various hydrophobic interaction columns, sizing columns, and several specific columns. These subsequent attempts to separate the remaining proteins were unsuccessful, resulting either in complete loss of activity or no further purification. Consequently, material from the Mono S column was used for subsequent culture studies.

\section{Comparison of FSH- and PSF-stimulated steroidogenesis in cultured rat granulosa cells}

The steroidogenic activities of PSF and FSH were compared by adding half-maximal doses of PSF $\left(400 \mathrm{ng} \mathrm{ml}^{-1}\right)$ or FSH (10 $\mathrm{ng} \mathrm{ml}^{-1}$ ) to freshly isolated granulosa cells in the presence of androstenedione $\left(10^{-7} \mathrm{~mol} \mathrm{l}^{-1}\right)$. Cultures were then stopped at various times over 7 days. FSH-stimulated progesterone accumulation (Fig. 3a) increased during the first 2 days of culture, reached peak values between 2 and 3 days, and then declined over the next 4 days. In contrast, PSF-stimulated progesterone accumulation gradually increased to a maximum at 5 days of culture. Although PSF-stimulated progesterone accumulation was lower than that of FSH during the first 3 days of culture, by day 5 it increased to an amount approximately equal to that seen with FSH at 3 days. The time course of $20 \alpha$-dihydroprogesterone accumulation was similar for both FSH- and PSF-treated cells, reaching peak values at 5 days of

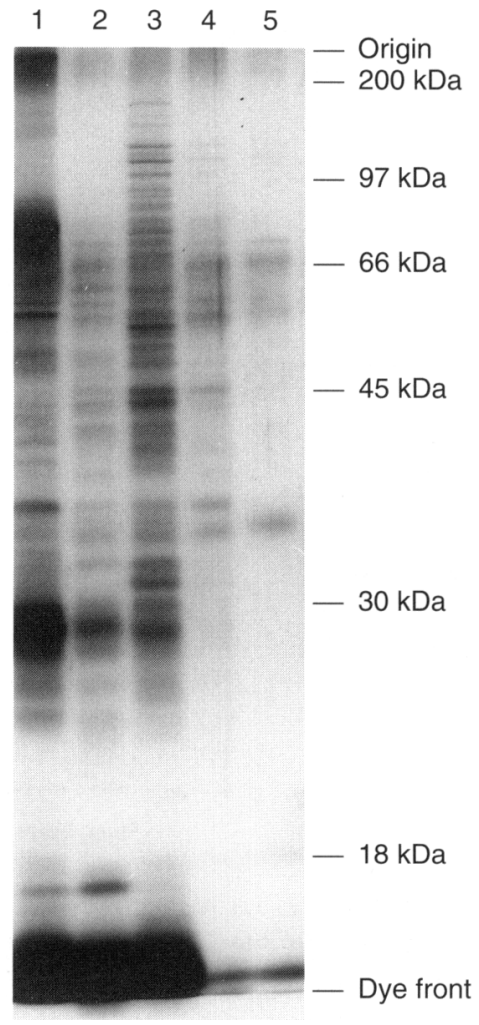

Fig. 2. SDS-PAGE of purification steps for progesterone-stimulating factor, with silver staining. Lane 1 : dialysate used as starting material for the progesterone-stimulating factor (PSF) preparation $(20 \mu \mathrm{g}$ protein); lane 2: active fractions from the first heparin-agarose chromatography ( $15 \mu \mathrm{g}$ protein); lane 3: active fractions from the second heparin-agarose chromatography ( $11 \mu \mathrm{g}$ protein); lane 4 : active fractions from the copper-chelating-Sepharose chromatography $(2.3 \mu \mathrm{g}$ protein) and; lane 5 , active fractions from the Mono $\mathrm{S}$ chromatography $(0.84 \mu \mathrm{g}$ protein). Migration of the molecular mass standards is indicated at the right. Similar results were obtained in four separate purifications.

culture (Fig. 3b). However, PSF consistently produced higher concentrations of 20a-dihydroprogesterone than did FSH, Downloaded from Bioscientifica.com at 04/26/2023 01:09:50PM 

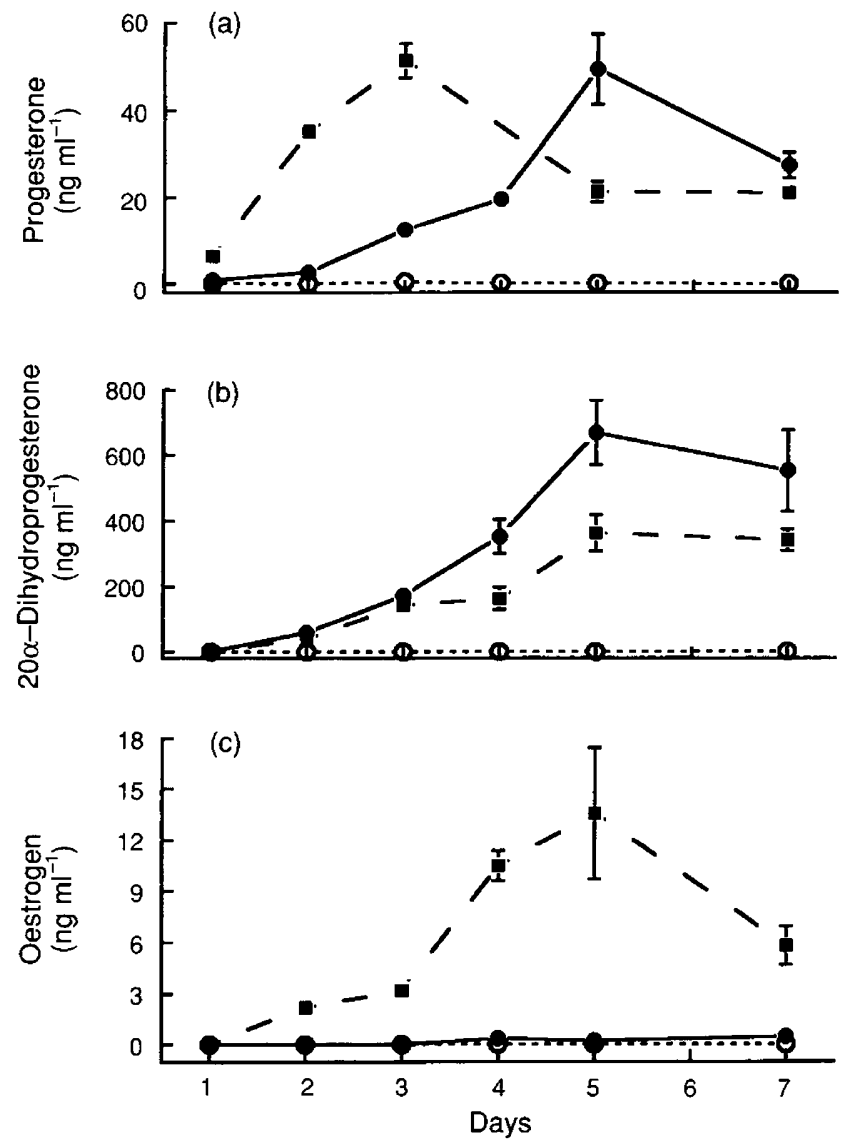

Fig. 3. Comparison of FSH- and progesterone-stimulating factor (PSF) stimulated steroidogenesis in rat granulosa cells. Granulosa cells $\left(5 \times 10^{4}\right.$ cells per well) were treated with FSH $\left(10 \mathrm{ng} \mathrm{ml}^{-1} ; \mathbf{\square}\right)$, PSF (400 $\mathrm{ng} \mathrm{ml}^{-1} ; 0$ ) or media alone $(0)$. Culture media was removed at the indicated times and stored at $-20^{\circ} \mathrm{C}$ until assayed for (a) progesterone, (b) 20a-dihydroprogesterone or (c) oestrogen. Data points are means \pm SEM of triplicate cultures from one of three independent experiments, all of which produced similar results. Error bars that are not shown are contained within the data point.

$667 \pm 97 \mathrm{ng} \mathrm{ml}^{-1}$ and $363 \pm 55 \mathrm{ng} \mathrm{ml}^{-1}$, respectively. Oestrogen accumulation followed a similar pattern, with both FSH and PSF treatment; however, PSF-stimulated oestrogen accumulation was less than $5 \%$ of that seen with FSH (Fig. 3c). Measurement of protein concentrations in these cultures revealed that, even though protein content of PSF- and FSH-treated cells was $25-40 \%$ higher than that of cells treated with media at 2, 3, 5 and 7 days, these increases were not statistically significant (data not shown).

\section{Comparison of PSF with FSH and EGF}

Because both PSF and FSH induced steroidogenic responses independently in granulosa cells, we next sought to determine whether the steroidogenic activity in PSF might be FSH. Initially, PSF was assayed for FSH immunoreactivity by radioimmunoassay. Increasing amounts of the FSH standard produced increasing competition in the radioimmunoassay (Fig. 4a); however, increasing amounts of PSF did not compete in the
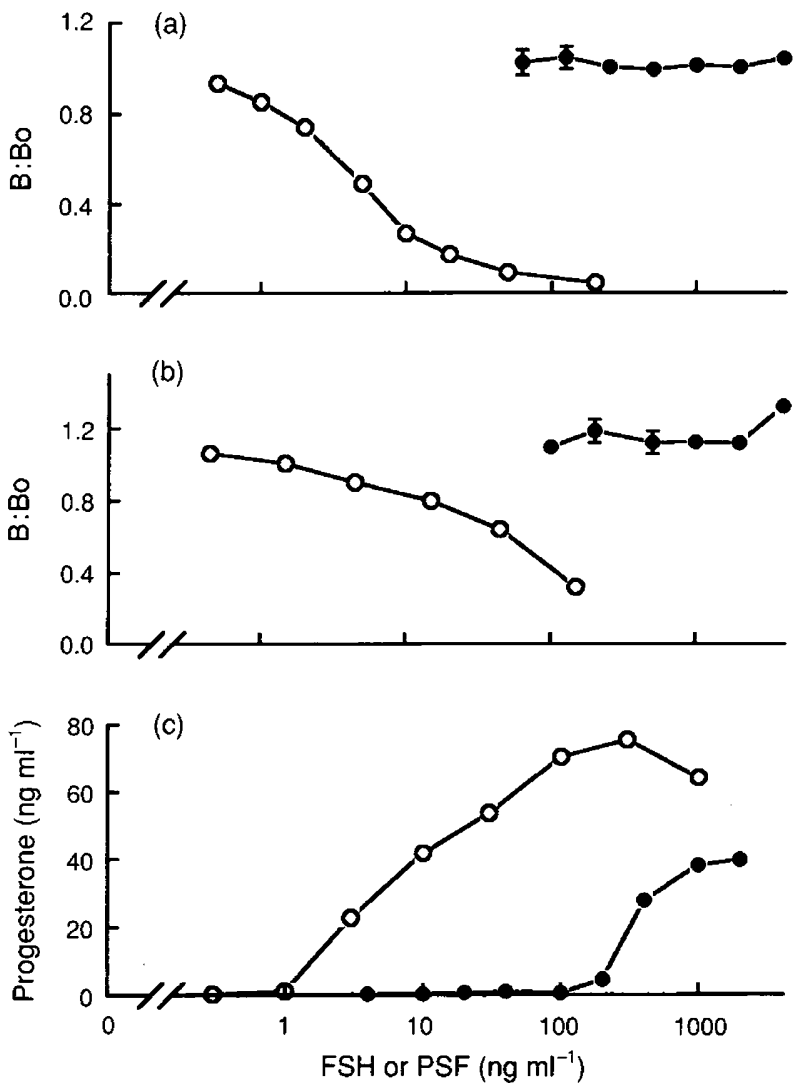

Fig. 4. FSH radioimmunoassay and $\mathrm{FSH}$ radioreceptor assay of progesterone-stimulating factor (PSF). Specific ${ }^{125}$ I-labelled FSH binding to (a) FSH antiserum or (b) granulosa cells, is indicated as B:Bo, with increasing amounts of either FSH (O) or PSF (O) added to the incubations. (c) Progesterone accumulation in granulosa cells after treatment with increasing amounts of FSH $(0,2$ days) or PSF ( 5 days). Data points in (a) and (b) are means \pm SEM from four independent experiments. Data points in (c) are means of triplicate samples from a single experiment. Error bars that are not shown are contained within the data point.

FSH radioimmunoassay, even when a dose eight times higher than that required to produce maximal steroidogenic activity (Fig. 4c) was used. Thus, doses of PSF that induce steroidogenic responses contain no measurable FSH immunoreactivity.

Although no FSH immunoreactivity was detected in PSF, it was possible that a bioactive, non-immunoactive form of FSH was present. Thus, PSF was tested in an FSH radioreceptor assay. Follicle-stimulating hormone competed for receptor binding in this assay (Fig. 4b), but PSF, even at a dose eight times higher than that producing maximal steroidogenic activity (Fig. 4c), again produced no competition. Thus, doses of PSF that induce steroidogenic responses contain no measurable FSH receptor binding activity. Similar studies also showed a lack of EGF activity in the PSF preparation (data not shown).

\section{Comparison of FSH and PSF induction of granulosa cell responsiveness to other agents}

In the next set of studies FSH and PSF induction of other differentiated responses in cultured rat granulosa cells were 

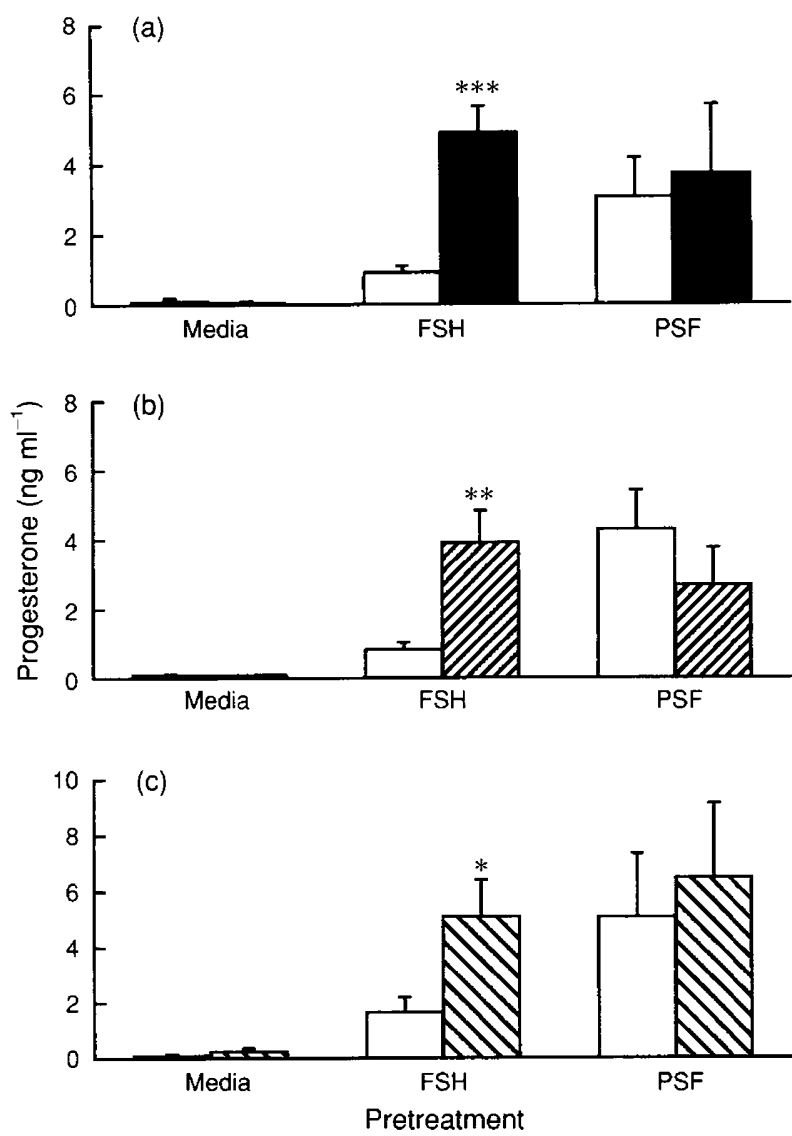

Fig. 5. Induction of hCG, prolactin and epidermal growth factor responsiveness in rat granulosa cells. Freshly isolated granulosa cells were pretreated with media alone, $\mathrm{FSH}\left(30 \mathrm{ng} \mathrm{ml}^{-1}\right)$ or progesteronestimulating factor (PSF; $1000 \mathrm{ng} \mathrm{ml}^{-1}$ ). After pretreatment for 5 days, the cells were washed, and then challenged with media alone ( $\square$ ), (a) hCG (30 $\left.\mathrm{g} \mathrm{ml}^{-1} \mathbf{D}\right)$, (b) prolactin (1 $\mu \mathrm{g} \mathrm{ml} \mathrm{m}^{-1}$ ए) or (c) epidermal

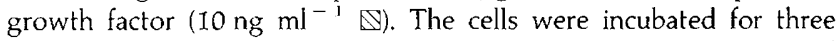
additional days and progesterone was measured by enzyme-linked immunoassay. Data points are means \pm SEM from either four ( $a$ and $b$ ) or six (c) independent experiments. ${ }^{*} P<0.05$ versus media treatment; $* * P<0.02$ versus media treatment; $* * * p<0.01$ versus media treatment.

compared. Cells were pretreated for either 2 or 5 days with FSH (30 ng ml ${ }^{-1}$ ) or PSF (1000 $\mathrm{ng} \mathrm{ml}^{-1}$ ); these doses produce maximal steroidogenic responses. After three washes with fresh media, cells were challenged for 3 days with media alone (control), hCG (30 $\left.\mathrm{n} \mathrm{ml}^{-1}\right)$, prolactin $\left(1 \mu \mathrm{g} \mathrm{ml}^{-1}\right)$, isoproterenol $\left(10^{-6} \mathrm{~mol}^{-1}\right)$, EGF $\left(10 \mathrm{ng} \mathrm{ml}^{-1}\right)$, FSH $\left(10 \mathrm{ng} \mathrm{ml}^{-1}\right)$ or PSF $\left(400 \mathrm{ng} \mathrm{ml}^{-1}\right)$. Pretreatment times of 2 and 5 days were chosen because they were the times of near maximal FSH- and PSF-stimulated progesterone accumulation, respectively.

Cells pretreated for 5 days with FSH, but not cells pretreated with PSF, showed a significant increase in hCG-stimulated progesterone accumulation $(P<0.01$ versus media controls, $n=6$ ) (Fig. 5a). Similar responses were also seen in cells pretreated for 2 days (data not shown). This apparent induction of LH/CG receptors was confirmed by binding experiments with ${ }^{125}$ I-labelled $\mathrm{hCG}$, which also showed that only cells pretreated with FSH possessed ${ }^{125}$ I-labelled hCG binding sites (data not shown). Similarly, cells pretreated for 5 days with
FSH, but again not those pretreated with PSF, showed a significant increase in prolactin-stimulated progesterone accumulation $(P<0.02$ versus media controls, $n=4$; Fig. $5 \mathrm{~b})$. A similar trend was observed in cells pretreated for 2 days, although the prolactin-stimulated increase in FSH-pretreated cells was not significant $(P<0.18$, prolactin versus media controls, $n=4$; data not shown).

Epidermal growth factor increases progestin synthesis in freshly isolated rat granulosa cells, although to much less an extent than does FSH (Jones et al., 1982; St-Arnaud et al., 1983). Therefore, the regulation of EGF responsiveness after pretreatment with either FSH or PSF was examined. Pretreatment of cells with FSH for 5 days increased subsequent responsiveness to EGF ( $P<0.05$ versus media controls, $n=6$; Fig. 5 c); however, a significant increase in EGF responsiveness was not observed after only 2 days of FSH treatment $(P<0.25 ; n=6$; data not shown). In contrast, pretreatment of cells with PSF for either 2 or 5 days did not increase subsequent responsiveness to EGF.

Binding studies have demonstrated the presence of $\beta$-adrenergic receptors in non-gonadotrophin-primed granulosa cells (Aguado and Ojeda, 1984). However, $\beta$-agonists do not stimulate steroidogenesis unless the cells are first treated with FSH (Adashi and Hsueh, 1981). Thus, as expected, granulosa cells pretreated with media alone did not produce progesterone in response to subsequent isoproterenol treatment (Fig. 6), whereas FSH-pretreated cells did acquire $\beta$-adrenergic responsiveness $(P<0.01$ versus media controls after 2 days, Fig. $6 a$, and $P<0.02$ versus media controls after 5 days, Fig. $6 \mathrm{~b}, n=6$ ). Pretreatment of cells with PSF also induced subsequent $\beta$-adrenergic responsiveness $(P<0.07$ versus media controls after 2 days, Fig. $6 \mathrm{a}$ and $P<0.05$ versus media controls after 5 days, Fig. $6 b, n=6$ ).

Comparison of maintenance of granulosa cell steroidogenesis by FSH and PSF

We determined whether pretreatment of granulosa cells with either PSF or FSH maintained subsequent responsiveness to these two substances. Granulosa cells were pretreated for 2 days with either media, FSH $\left(30 \mathrm{ng} \mathrm{ml}^{-1}\right.$ ) or PSF (1000 ng $\mathrm{ml}^{-1}$ ), and then challenged for 3 days with one of these substances (Fig. 7). Compared with media-pretreated cells, FSH-pretreated cells were significantly more responsive to subsequent challenge with FSH $(P<0.02, n=6)$ or PSF $(P<0.05, n=6)$. Pretreatment with FSH also induced a higher rate of basal progesterone production, which was apparent even after treatment with media for 3 days $(P<0.01, n=6)$. Pretreatment with FSH for 5 days also maintained subsequent responsiveness to FSH or PSF (data not shown). We also examined the ability of pretreatment with PSF to maintain subsequent responsiveness to either PSF or FSH; however, unlike that with FSH, pretreatment with PSF did not maintain subsequent responsiveness to challenge with either $\mathrm{FSH}$ or PSF $(P>0.05, n=6)$. Nonetheless, pretreatment with PSF did induce higher concentrations of basal progesterone production than did pretreatment with FSH $(P<0.01$, $n=6$ ). 


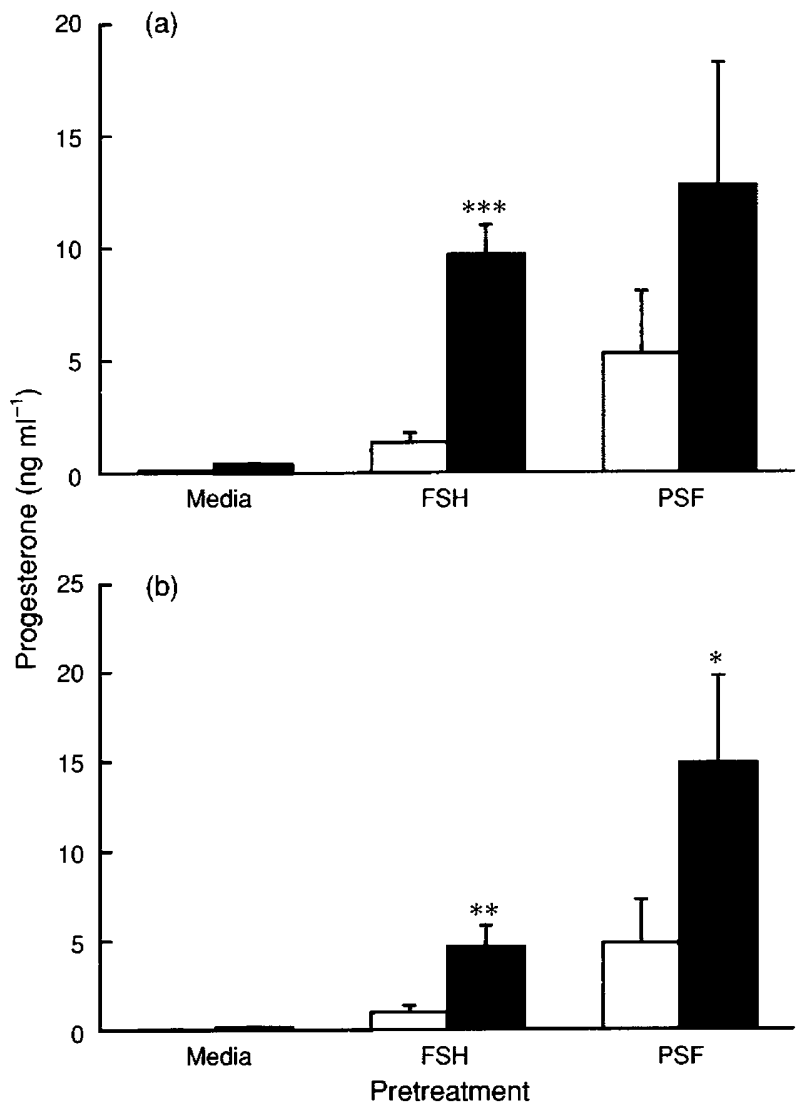

Fig. 6. Induction of $\beta$-adrenergic responsiveness in rat granulosa cells. Freshly isolated granulosa cells were pretreated with media alone, FSH $\left(30 \mathrm{ng} \mathrm{ml}{ }^{-1}\right.$ ) or progesterone-stimulating factor (1000 $\mathrm{ng} \mathrm{ml}^{-1}$ ). After pretreatment for (a) 2 days or (b) 5 days, the cells were washed, and then challenged with media alone ( $\square$ ) or isoproterenol $\left(10^{-6} \mathrm{~mol} \mathrm{l}^{-1} ; \boldsymbol{D}\right)$. The cells were incubated for a further 3 days and progesterone was measured by enzyme-linked immunoassay. Data points are means \pm SEM from six independent experiments. ${ }^{*} P<0.05$ versus media treatment; ${ }^{* *} P<0.02$ versus media treatment; $* * * P<0.01$ versus media treatment.

\section{Discussion}

In the study reported here a progesterone-stimulating factor secreted by concanavalin A-stimulated rat splenocytes was purified over 500-fold and it was determined that this factor, like $\mathrm{FSH}$, stimulated both progesterone and 20a-dihydroprogesterone production but, unlike FSH, stimulated only a minimal amount of oestrogen production. When compared in the same cultures, PSF maximally stimulated approximately the same amount of progesterone as did FSH, but required a substantially longer time to do so. This is in contrast to other agents, including EGF, GnRH, VIP and PACAP, that independently stimulate only $10-30 \%$ the amount of progesterone seen in response to FSH but do so with time courses similar to that of FSH (Clark, 1982; Jones et al., 1982; Davoren and Hsueh, 1985; Zhong and Kasson, 1994). PSF also stimulated nearly twice the amount of $20 \alpha$-dihydroprogesterone as did FSH; however, the time course for this effect was similar to that of FSH.

Even though these initial studies revealed differences between the steroidogenic activity of PSF and the other agents

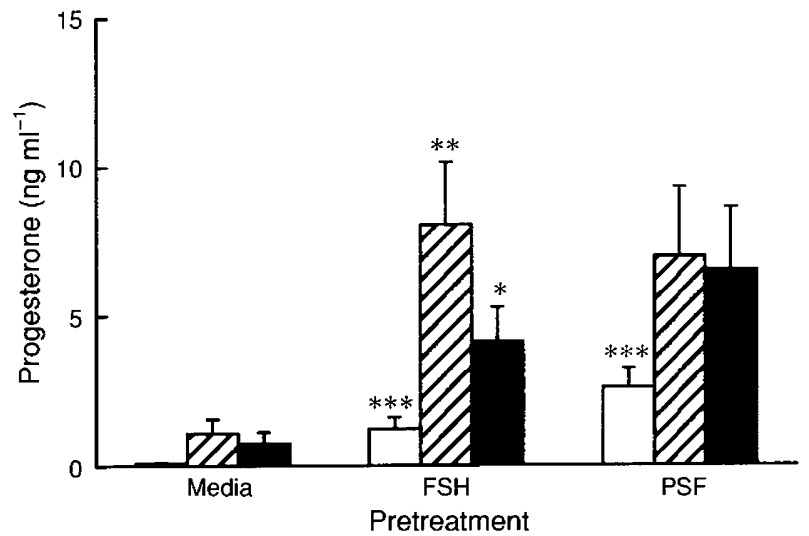

Fig. 7. Maintenance of FSH and progesterone-stimulating factor, PSF, responsiveness in rat granulosa cells. Freshly isolated granulosa cells were pretreated with media alone, FSH (30 $\mathrm{ng} \mathrm{ml}^{-1}$ ) or PSF (1000 ng $\mathrm{ml}^{-1}$ ). After pretreatment for 2 days, the cells were washed, and then challenged with media alone ( $\square$ ), FSH (10 $\left.\mathrm{ng} \mathrm{ml}^{-1} ; \square\right)$ or PSF (400 $\left.\mathrm{ng} \mathrm{ml}^{-1}, \mathbf{\square}\right)$. The cells were incubated for a further 3 days and progesterone concentration was measured by enzyme-linked immunoassay. Data points are means \pm SEM from six independent experiments. ${ }^{*} P<0.05$ versus media treatment; ${ }^{*} P<0.02$ versus media treatment; $* * * P<0.01$ versus media treatment.

described above, we determined whether the activity of PSF might still result from the presence of one of these other agents. Initial experiments demonstrated that the steroidogenic activity of PSF could not be attributed to the presence of an FSH-like molecule, because PSF did not contain FSH immunoreactivity nor did it contain FSH receptor-binding activity. Moreover, PSF activity could not be attributed to an EGF-like molecule, because PSF did not contain EGF receptor-binding activity. It was thought unlikely that the other smaller peptides (GnRH, VIP and PACAP) could be responsible for the steroidogenic activity of PSF, because they would have been removed during the dialysis and subsequent chromatographic steps used in the purification of PSF. Consequently, these data indicate that PSF is distinct from FSH, EGF, GnRH, VIP and PACAP.

The chromatographic procedure used in the purification of PSF from conditioned splenocyte media isolated two distinct progesterone-stimulating activities; one activity flowed through the heparin-agarose column and one activity bound to the column but could be eluted by $\mathrm{NaCl}$. The non-retained activity was difficult to detect upon heparin-agarose chromatography (25-150 min) probably because of its low concentration in the eluant. However, it was clearly present upon DEAE chromatography of dialysate. Initial characterization of this activity showed that it was quite different from the heparin-binding material, and was much more anionic and much larger in apparent size; whether this activity is related to the heparin-binding activity is unclear. The heparin-binding activity was purified over 500 times from material present in the splenocyte culture supernatants; however, the active fractions from the Mono $S$ column still contained several proteins as assessed by SDS-PAGE. Subsequent attempts to purify this activity further to a single protein band resulted either in complete loss of activity or no further purification. Thus, two or more of the proteins seen on SDS-PAGE may be required to 
elicit the steroidogenic activity present in this preparation, or the remaining proteins may have very similar physical and chemical properties, making them difficult to separate by chromatography.

While the steroidogenic activities of PSF and FSH showed similarities, their actions with regard to the induction of granulosa cell responsiveness to other agents differed markedly. As demonstrated here and by Hsueh et al. (1984), pretreatment of granulosa cells with FSH induced subsequent responsiveness to $\mathrm{LH} / \mathrm{CG}$, prolactin and isoproterenol; however, pretreatment with PSF induced responsiveness only to isoproterenol. Previous work has shown fundamental differences in the induction of these three responses. Binding studies have demonstrated the presence of $\beta$-adrenergic receptors on the surface of freshly isolated rat granulosa cells (Aguado and Ojeda, 1984), but activation of these receptors with $\beta$-agonists does not stimulate steroid production unless the cells have been previously exposed to FSH (Adashi and Hsueh, 1981). This type of data has been interpreted as indicating that FSH is required to couple $\beta$-adrenergic receptors to adenylate cyclase. In contrast, $\mathrm{LH} / \mathrm{CG}$ and prolactin receptors are not present on the surface of freshly isolated rat granulosa cells but, following exposure to $\mathrm{FSH}$, these receptors are induced through gene transcription and translation (Wang et al., 1979; Hu and Dufau, 1991; Piquette et al., 1991). Thus, the present results suggest that PSF may be able to induce coupling of $\beta$-adrenergic receptors to adenylate cyclase, but may not be able to induce the transcriptional and translational processes necessary to produce granulosa cell responsiveness to $L H / C G$ and prolactin.

Although the actions of a variety of cytokines on granulosa cells have been investigated (Kasson and Gorospe, 1989; Adashi et al., 1989; Gorospe et al., 1992; Dorrington et al., 1993), PSF remains essentially unique in that it can independently stimulate steroidogenesis in non-gonadotrophin-primed cells. Only one other immune cell-derived activity, produced by peritoneal macrophages, increases progesterone production in a dose-dependent manner in human and mouse luteinized granulosa cells (Kirsch et al., 1981; Halme et al., 1985). This activity has characteristics similar to those of the splenocytederived activity investigated here, in that both are heat- and trypsin-sensitive, stimulated by concanavalin $A$ and have two apparent sizes on gel filtration chromatography, 26 and $41 \mathrm{kDa}$ for the macrophage activity (Kirsch et al., 1983) and 27 and $55 \mathrm{kDa}$ for the splenocyte activity (Ness and Kasson, 1993). However, unpublished, preliminary studies (J. M. Ness and B. G. Kasson) have shown that the splenocyte activity is associated with slowly adherent splenocytes (thought to be lymphocytes) rather than rapidly adherent splenocytes (thought to be macrophages). Although some of the characteristics of PSF resemble those of the macrophage factor, these two factors are apparently produced by different types of cell.

In the present study, several characteristics of PSF activity, but not their potential physiological roles, have been defined. Because PSF activity is produced by splenocytes, which are composed mainly of lymphocytes with a limited number of macrophages, it is possible that PSF activity secreted from these leukocytes, either in the spleen or in the circulation, could affect ovarian function through an endocrine mechanism.
Alternatively, because $\mathrm{T}$ lymphocytes and macrophages are also present within rat ovaries (Adashi, 1990; Brännström et al., 1993), intraovarian leukocytes may produce this activity, which could then affect ovarian function through a paracrine mechanism. Although physiological stimulators of PSF activity have not yet been identified, concanavalin A binding sites within the ovary have been documented (Lee and Ryan, 1979; Hsueh et al., 1984). These sites may represent receptors for physiological stimulators of PSF that are nonspecifically activated by concanavalin A. The nature of these sites and their potential relationship to PSF remains to be investigated.

The present study showed that PSF stimulates progestin production but does not induce significant oestrogen production or any other differentiated functions of granulosa cells. These observations, combined with the finding of Brännström et al. (1993) that the number of certain ovarian leukocyte subtypes increases during the luteal phase of the cycle, suggest that PSF may play a more significant role during the luteal phase of the cycle, when there is prominent progestin production, rather than during the follicular phase of the cycle. However, further studies on when and where PSF may be produced within the ovary are required to establish these hypotheses. Nonetheless, in the light of the very limited number of factors that independently stimulate granulosa cell function, the actions of PSF are unique. The activity of PSF may provide an important link between intraovarian leukocytes and the regulation of ovarian function as well as a mechanism for diversifying the regulation of steroidogenesis in granulosa and luteal cells.

This work was supported by grants from the National Science Foundation (IBN 90-05182) and the University of Iowa Diabetes and Endocrinology Research Center (DK-25295).

\section{References}

Adashi EY (1990) The potential relevance of cytokines to ovarian physiology: the emerging role of resident ovarian cells of the white blood series Endocrine Reviews 11 454-464

Adashi EY and Hsueh AJW (1981) Stimulation of $\beta_{2}$-adrenergic responsiveness by follicle-stimulating hormone in rat granulosa cells in vitro and in vivo Endocrinology 108 2170-2178

Adashi EX, Resnick CE, Croft CS and Payne DW (1989) Tumor necrosis factor- $\alpha$ inhibits gonadotropin hormonal action in nontransformed ovarian granulosa cells. A modulatory noncytotoxic property Journal of Biological Chemistry $26411591-11597$

Aguado LI and Ojeda SR (1984) Prepubertal ovarian function is finely regulated by direct adrenergic influences. Role of noradrenergic innervation Endocrinology 114 1845-1853

Bradford MM (1976) A rapid and sensitive method for quantitation of microgram quantities of protein utilizing the principle of protein-dye binding Analytical Biochemistry 72 248-252

Brännström M, Mayrhofer G and Robertson SA (1993) Localization of leukocyte subsets in the rat ovary during the periovulatory period Biology of Reproduction 48 277-286

Clark MR (1982) Stimulation of progesterone and prostaglandin $E_{2}$ accumulation by luteinizing hormone-releasing hormone (LHRH) and LHRH analogues in rat granulosa cells Endocrinology 110 146-152

Davoren IB and Hsueh AJW (1985) Vasoactive intestinal peptide: a novel stimulator of steroidogenesis by cultured rat granulosa cells Biology of Reproduction 33 37-52

Dorrington JH, Bendell JJ and Khan SA (1993) Interactions between FSH, estradiol-17 $\beta$ and transforming growth factor- $\beta$ regulate growth and Downloaded from Bioscientifica.com at 04/26/2023 01:09:50PM 
differentiation in the rat gonad Journal of Steroid Biochemistry and Molecular Biology 44 441-447

Gorospe WC and Kasson BG (1988) Lymphokines from concanavalin Astimulated lymphocytes regulate rat granulosa cell steroidogenesis in vitro Endocrinology 123 2462-2471

Gorospe WC, Hughes FM and Spangelo BL (1992) Interleukin-6: effects on and production by rat granulosa cells in vitro Endocrinology 130 $1750-1752$

Halme J, Hammond MG, Syrop CH and Talbert LM (1985) Peritoneal macrophages modulate human granulosa-luteal cell progesterone production Journal of Clinical Endocrinology and Metabolism 61 912-916

Hsueh AJW, Adashi EY, Jones PBC and Welsh TH (1984) Hormonal regulation of the differentiation of cultured ovarian granulosa cells Endocrine Reviews $\mathbf{5}$ $76-127$

Hu Z-Z and Dufau ML (1991) Multiple and differential regulation of ovarian prolactin receptor messenger RNAs and their expression Biochemical and Biophysical Research Communications 181 219-225

Jones PBC, Welsh TH, Jr and Hsueh AJW (1982) Regulation of ovarian progestin production by EGF in cultured rat granulosa cells Journal of Biological Chemistry 257 11268-11273

Kasson BG and Gorospe WC (1989) Effects of interleukins 1, 2 and 3 on follicle-stimulating hormone-induced differentiation of rat granulosa cells Molecular and Cellular Endocrinology 62 103-111

Kirsch TM, Friedman AC, Vogel RL and Flickinger GL (1981) Macrophages in corpora lutea of mice: characterization and effects on steroid secretion Biology of Reproduction 25 629-638

Kirsch TM, Vogel RL and Flickinger GL (1983) Macrophages: a source of luteotropic cybernins Endocrinology 113 1910-1912
Laemmli UK (1970) Cleavage of structural proteins during the assembly of the head of bacteriophage T4 Nature 227 680-685

Lee $C Y$ and Ryan RJ (1979) The porcine ovarian follicle. V. Binding of concanavalin A to granulosa cells during follicle maturation Biology of Reproduction 21 973-982

Miyachi Y, Vaitukaitis JL, Nieschlag E and Lipsett MB (1972) Enzymatic radioiodination of gonadotropins Journal of Clinical Endocrinology and Metabolism $3423-28$

Ness JM and Kasson BG (1993) Purification and characterization of a progesterone stimulating factor from cultured rat splenocytes. In 75th Annual Meeting of the Endocrine Society Las Vegas, NV, Abstract 2.33

Piquette GN, LaPolt PS, Oikawa M and Hsueh AJW (1991) Regulation of luteinizing hormone receptor messenger ribonucleic acid levels by gonadotropins, growth factors and gonadotropin-releasing hormone in cultured rat granulosa cells Endocrinology 128 2449-2456

St-Arnaud R, Walker P, Kelly PA and Labrie F (1983) Rat ovarian epidermal growth factor receptors: characterization and hormonal regulation Molecular and Cellular Endocrinology $31.43-52$

Veldhuis JD, Garmey JC, Urban RJ, Demers LM and Aggarwal BB (1991) Ovarian actions of tumor necrosis factor- $\alpha$ : pleiotropic effects of TNF- $\alpha$ on differentiated functions of untransformed swine granulosa cells Endocrinology 129 641-648

Wang C, Hsueh AJW and Erickson GF (1979) Induction of functional prolactin receptors by follicle-stimulating hormone in rat granulosa cells in vivo and in vitro Journal of Biological Chemistry $25411330-11336$

Zhong Y and Kasson BG (1994) Pituitary adenylate cyclase activating polypeptide stimulates steroidogenesis and CAMP production by cultured rat granulosa cells Endocrinology 135 207-213 